\title{
Airway inflammatory profile among cleaning workers from different workplaces
}

\section{Edineia Rosa da Paz}

Institute of Medical Assistance to the State Public Servant: lamspe

\section{Cynthia Mafra Fonseca de Lima}

FMUSP: Universidade de Sao Paulo Faculdade de Medicina

\section{Soraia Nogueira Felix ( $\nabla$ soraia.ank@gmail.com )}

Instituto de Assistência Médica ao Servidor Público Estadual: lamspe https://orcid.org/0000-00017353-5100

\section{Bruna Schaeffer}

UNICID: Universidade Cidade de Sao Paulo

\section{Clóvis Eduardo Santos Galvão}

HCFMUSP: Universidade de Sao Paulo Hospital das Clinicas

\section{Aristides Tadeu Correia}

USP Incor: Universidade de Sao Paulo Instituto do Coracao

\section{Renato Fraga Righetti}

FMUSP: Universidade de Sao Paulo Faculdade de Medicina

\section{Milton de Arruda Martins}

FMUSP: Universidade de Sao Paulo Faculdade de Medicina

Iolanda de Fátima Lopes Calvo Tibério

FMUSP: Universidade de Sao Paulo Faculdade de Medicina

\section{Beatriz Mangueira Saraiva Romanholo}

FMUSP: Universidade de Sao Paulo Faculdade de Medicina

\section{Research article}

Keywords: Cleaning workers, work-related asthma, work-related rhinitis, respiratory symptoms, nasal swab

Posted Date: May 12th, 2021

DOl: https://doi.org/10.21203/rs.3.rs-488777/v1

License: (c) (1) This work is licensed under a Creative Commons Attribution 4.0 International License. Read Full License 


\section{Abstract}

Background: Cleaning workers represent a significant proportion of the active population worldwide, with poor remuneration, particularly in developing countries. Despite this, they remain a relatively poorly studied occupational group. They are constantly exposed to agents that can cause symptoms and respiratory problems.

Objective: To investigate the airway inflammation and respiratory symptoms of cleaning workers from different workplaces.

Methods We performed a cross-sectional study on the prevalence of upper airway inflammation and symptoms of asthma/rhinitis related to cleaning work, according to workplace.167 participants were divided into four groups: Hospital (H), University (U), Housekeeper (Ho) and Control (C). A nasal swab was collected for upper airway inflammation evaluation. Clinical profiles and respiratory symptom employee evaluations were performed using specific questionnaires (ECRHS and ISAAC).

Results: Cleaning workers showed increased neutrophils and lymphocytes; Hospital and University showed increased macrophages compared to the Housekeeper and Control. Hospital and Housekeeper showed increased eosinophils when they performed cleaning services for up to one year and also reported having more asthma symptoms than the Control. Cleaning workers showed increased rhinitis symptoms. The University group showed increased rhinitis symptoms aggravated by the workplace compared with the Hospital and Housekeeper. Cleaning workers showed an increased affirmative response when direct asked about rhinitis symptoms compared to Control.

Conclusions: Cleaning workers showed airway inflammation, asthma symptoms and rhinitis, regardless of the occupational environment to which they were exposed and also showed increased rhinitis and asthma symptoms. Hospital cleaning workers showed increased macrophages, lymphocytes and eosinophils compared to the others. The length of time spent performing cleaning work was not related to nasal inflammation or respiratory symptoms in this population. However, there are differences in workplaces.

Clinical Trial registration number NCT03311048, October 16, 2017. Availble at: https://clinicaltrials.gov/ct2/show/NCT03311048 (retrospectively registered).

\section{Introduction}

Occupational asthma (OA) refers to asthma induced by exposure in the working environment, with or without pre-existing asthma [1]. The British Occupational Health Research Foundation (BOHRF) review concluded that occupational factors account for one in six cases of asthma in adults of working age [2]. Inhaled agents in a workplace environment may lead to asthma by sensitization, by creating airway inflammation, or by irritant reflex pathways [3]. 
Cleaning activities seem to represent an important risk and an important portion of workers who have asthma symptoms related to cleaning materials have a pattern of bronchial reaction consistent with occupational asthma induced by sensitizer [4]. In the city of São Paulo, cleaning was the main occupation in terms of the number of cases of occupational asthma among women, and cleaning products were the most frequently reported agent between 1995 and 2000 [5].

Cleaning products and disinfectants may be irritant or sensitizers (or both) [6]. When work-related asthma is suspected, confirmatory examination and identification shall be indicated whether the agent is sensitizing or irritant in order to provide guidance where possible to avoid exposure and appropriate pharmacological treatment [7].

Occupational Asthma can be mediated by IgE, caused by specific agents with unknown mechanism or irritants [8]. The mechanisms involved in asthma associated with cleaning products and disinfectants are unclear. Both allergic and irritating mechanisms are involved, but the irritant mechanism seems to be more relevant. The inflammatory response Th2 is caused after damage to the airway epithelium as a result of continuous exposure to the irritant [9].

OA induced by IgE-dependent agents is similar to allergic asthma that is unrelated to work. Most highmolecular-weight compounds (greater/equal 5000 daltons) induce asthma by producing specific IgE antibodies. Some low-molecular-weight compounds (< 5000 daltons), such as acid anhydrides and platinum salts, act as haptens and induce specific IgE antibodies by combining with a body protein [10]. Preformed and newly formed inflammatory mediators are released, and they orchestrate the inflammatory process [11].

For many low-molecular-weight compounds, specific IgE antibodies have not been found or have been found in only a small proportion of patients [12]. When these antibodies are present, they may be markers of exposure and not causes of disease. The role of T lymphocytes in the pathogenesis of asthma and occupational asthma is under intense study [13]. T lymphocytes may be directly involved in the inflammatory process rather than acting through the induction and suppression of IgE synthesis [13]. Pathologic airway changes are similar to those in patients with other forms of asthma [14].

Although cleaners represent a significant proportion of the working population worldwide, they remain a relatively understudied occupational group. Cleaning workers represent a significant proportion of the active population worldwide, with poor remuneration, particularly in developing countries. They are constantly exposed to agents that can cause symptoms and respiratory problems $[15,16]$.

However, the objectives of the present study were to measure airway inflammation in professional cleaning workers in three different occupational settings by comparing nasal cytology inflammation and clinical profiles.

\section{Methods}




\section{Study design, ethics statement and trial registration}

This was a cross-sectional study on the prevalence of upper airway inflammation and symptoms of asthma/rhinitis related to cleaning work, according to the place of employment, approved by the IAMSPE Research Ethics Committee (protocol number 1514913.3.0000.5463, approval 2.426.900) (S1), Trial registration: Clinical Trials NCT03311048 (https://clinicaltrials.gov/ct2/show/NCT03311048) (retrospectively registered). The STROBE cross sectional reporting guidelines was used in this study (S2) [15].

\section{Study population}

Recruitment and data collection took place from April 2015 to December, 2017, in the city of Cacoal, state of Rondônia, Brazil, and included cleaning workers divided into four groups:I

(A) hospital: individuals working in hospital cleaning;

(B) university: individuals working in university cleaning;

(C) housekeeper: individuals working in professional cleaning in people's homes; and

(D) control: individuals working in offices.

Active smokers, pregnant women, infants, and individuals on ongoing treatment for airway disorders were excluded from the study. All cleaning workers from each selected location (university, hospital, housekeeper and control) were invited and all those who agreed to participate in the study and who did not meet any exclusion criteria were included.

\section{Demographic and work characteristics}

Cleaning workers from all experimental groups answered a questionnaire demographic and work characteristics, besides main substances used to clean.

\section{Questionnaires}

Information on respiratory symptoms was collected using a translation of the European Community Respiratory Health Survey (ECRHS) for occupational diseases evaluation[17], translated and validated into Portuguese [18] and the International Study of Asthma and Allergies in Childhood (ISAAC) asthma and rhinitis modules [19]. The asthma module had previously been validated in Portuguese [20]. Additionally, information about symptom onset and cleaning-related airway symptoms was obtained.

\section{Nasal swab test}

The nasal swab protocol was described by Ronchetti et al. [21]. A sterile swab was used (Johnson \& Johnson, Brazil). Twenty minutes after collection, the slides were stained using May-Grunwald-Giemsa for identification of eosinophils, neutrophils, lymphocytes, macrophages and epithelial cells. Cells were 
analysed using a Nikon E600 (Nikon, Canada) optical microscope with a magnitude of 1000x. A total of 200 cells were counted on two slides [21].

\section{Statistical analyses}

Statistical analysis was performed using the Kruskal-Wallis test and the Dunn test for comparisons between groups. To evaluate the association between the qualitative variables, the chi-square test was used. The statistical software SigmaPlot 12.0 (Systat Software, San Jose, CA) and SPSS 21.0 (IBM, USA) were used for the analyses. The confidence interval was $95 \%(p<0.05)$.

\section{Results}

\section{Study population}

A total of 167 workers were recruited to participate in this study: 56 hospital cleaners, 29 university cleaners, 34 housekeepers and 39 office workers. Nine patients were excluded from the study because they presented the exclusion criteria (Fig. 1).

\section{Demographic and work characteristics}

The majority of the participants were female (84.4\%) and most of the subjects worked full time (Tables 1A and 1B). The cleaning products most used were bleaches, disinfectants, alcohol, detergents and others (Table 1C). 
Table 1

Baseline characteristics and main products or substances by job location

$\begin{array}{llll}\text { Hospital } & \text { University } & \text { Housekeeper } & \text { Control } \\ \begin{array}{l}\text { Mean }( \pm \\ \text { sd) }\end{array} & \text { Mean }( \pm \text { sd }) & \text { Mean }( \pm s d) & \text { Mean }( \pm s d)\end{array}$

\section{A. Demographic} characteristics

Age (year) $( \pm s d)$

$36.6(8.4) \quad 36.8(9.5)$

$37.5(11.0)$

27.6

(6.3)

Hospital University

Housekeeper

Control

$N(\%)$

$\mathbf{N}(\%)$

$\mathbf{N}(\%)$

$N(\%)$

Sex

Male

$12(21.4) \quad 5(12.8)$

$1(2.9)$

$8(21.1)$

Female

44 (78.6) $\quad 34(87.2)$

33 (97.1)

30

$56(33.5)$

$39(23.3)$

$34(20.3)$

B. Job characteristics

Work shift

Day

$24(21.6)$

$27(24.3)$

$22(19.8)$

Night

$1(50.0)$

$0(0.0)$

$1(50.0)$

$0(0.0)$

Varied

31 (57.4)

$12(22.2)$

$11(20.4)$

$0(0.0)$

Hours worked per week

40 (full-time)

$52(33.1) \quad 39(24.8)$

$28(17.8)$

38

36 (part-time)

$4(40.0)$

$0(0.0)$

$6(60.0)$

$0(0.0)$

C. Main substances

used

Product

Total

Bleach

$28(38.3) \quad 20(27.4)$

$25(34.2)$

73 


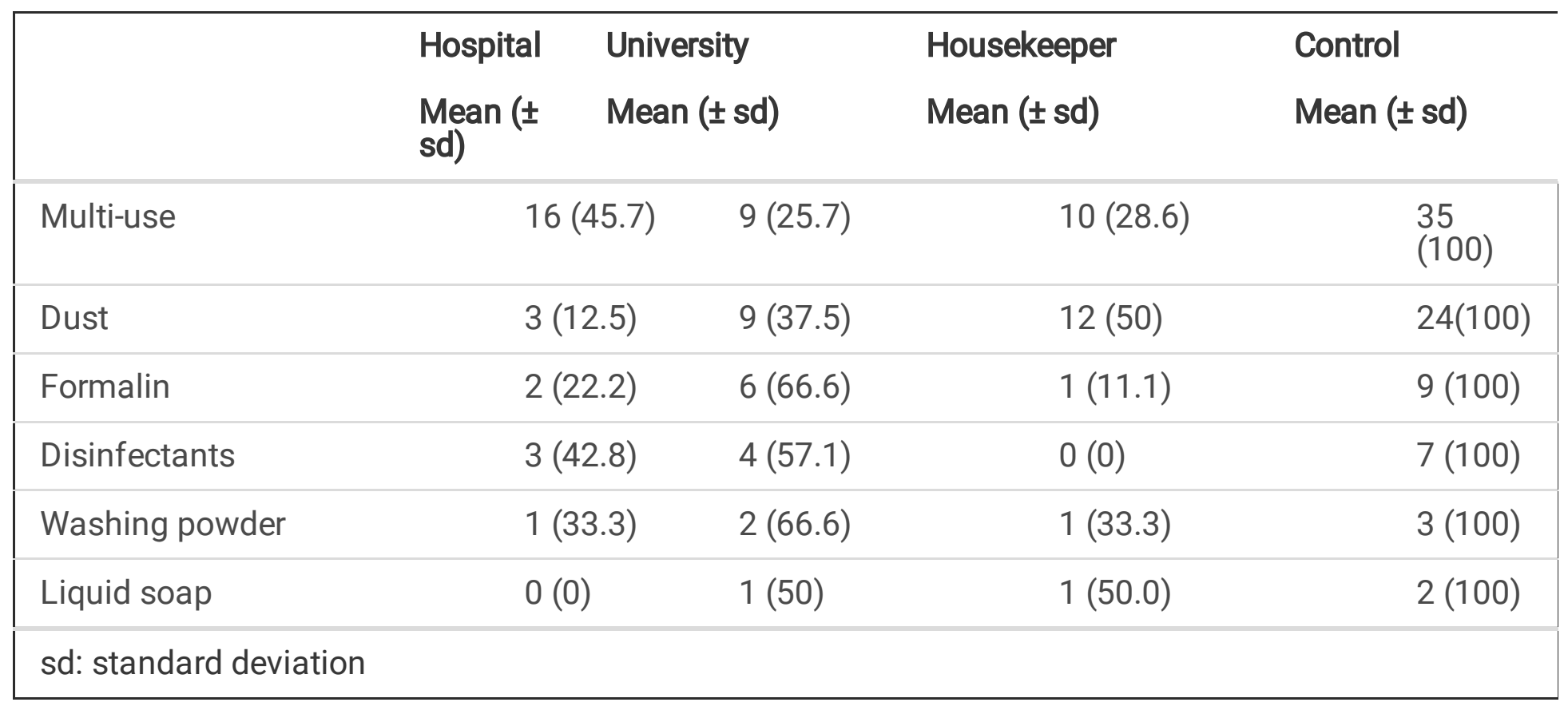

The most common work practices reported were scrubbing; washing; polishing; waxing; cleaning of carpets, vases, windows and kitchen; dusting, carpet tapping, using the washing machine and hand washing (Table 2). 
Table 2

Main work tasks performed by cleaning workers

\begin{tabular}{|c|c|c|c|c|c|}
\hline Activity & Frequency & $\begin{array}{l}\text { Hospital } \\
\text { n (\%) }\end{array}$ & $\begin{array}{l}\text { University } \\
\text { n (\%) }\end{array}$ & $\begin{array}{l}\text { Housekeeper } \\
\text { n (\%) }\end{array}$ & $\begin{array}{l}\text { Control } \\
\text { n (\%) }\end{array}$ \\
\hline \multirow{4}{*}{$\begin{array}{l}\text { Dusting, } \\
\text { carpet cleaning }\end{array}$} & Daily & $14(26.4)$ & $24(45.3)$ & $15(28,3)$ & $0(0,0)$ \\
\hline & No & $40(38.1)$ & $15(14.3)$ & $12(11.4)$ & $38(36.2)$ \\
\hline & Fortnightly & $1(25.0)$ & $0(0.0)$ & $3(75,0)$ & $0(0.0)$ \\
\hline & 2x week & $1(20.0)$ & $0(0.0)$ & $4(80,0)$ & $0(0.0)$ \\
\hline \multirow[t]{4}{*}{ Scrub, wash } & Daily & $50(46.3)$ & $35(32.4)$ & $23(21,3)$ & $0(0.0)$ \\
\hline & No & $6(11.3)$ & $4(7.5)$ & $5(9,4)$ & $38(71.7)$ \\
\hline & Fortnightly & $0(0.0)$ & $0(0.0)$ & $1(100.0)$ & $0(0.0)$ \\
\hline & 2x week & $0(0.0)$ & $0(0.0)$ & $1(100.0)$ & $0(0.0)$ \\
\hline \multirow{4}{*}{$\begin{array}{l}\text { Cleaning of sinks and } \\
\text { sanitary ware }\end{array}$} & Daily & $23(47.7)$ & $31(27.9)$ & $27(24.3)$ & $0(0.0)$ \\
\hline & No & $3(5.7)$ & $8(15.1)$ & $4(7.5)$ & $38(71.7)$ \\
\hline & Fortnightly & $0(0.0)$ & $0(0.0)$ & $3(100,0)$ & $0(0.0)$ \\
\hline & $2 x$ week & $0(0.0)$ & $0(0.0)$ & $0(0.0)$ & $0(0.0)$ \\
\hline \multirow[t]{4}{*}{ Polishing, waxing } & Daily & $6(17.1)$ & $26(74.3)$ & $3(8.6)$ & $0(0.0)$ \\
\hline & No & $48(37.8)$ & $13(10.2)$ & $28(22.0)$ & $38(29.9)$ \\
\hline & Fortnightly & $2(40.0)$ & $0(0.0)$ & $3(60.0)$ & $0(0.0)$ \\
\hline & 2x week & $0(0.0)$ & $0(0.0)$ & $0(0.0)$ & $0(0.0)$ \\
\hline \multirow[t]{4}{*}{ Window cleaning } & Daily & $42(49.4)$ & $26(30.6)$ & $17(20.0)$ & $0(0.0)$ \\
\hline & No & $5(8.1)$ & $13(21.0)$ & $6(9.7)$ & $38(61.3)$ \\
\hline & Fortnightly & $8(57.1)$ & $0(0.0)$ & $6(42.9)$ & $0(0.0)$ \\
\hline & 2x week & $1(16.7)$ & $0(0.0)$ & 5 (83.3) & $0(0.0)$ \\
\hline \multirow[t]{4}{*}{ Kitchen cleaning } & Daily & $16(43.2)$ & $12(32.4)$ & 9 (24.3) & $0(0.0)$ \\
\hline & No & $39(32.2)$ & $26(21.5)$ & $18(14.9)$ & 38 (314) \\
\hline & Fortnightly & $0(0.0)$ & $0(0.0)$ & $0(0.0)$ & $0(0.0)$ \\
\hline & 2x week & $1(11.1)$ & $1(11.1)$ & $7(77.8)$ & $0(0.0)$ \\
\hline \multirow{2}{*}{$\begin{array}{l}\text { Handwashing } \\
\text { (clothing) }\end{array}$} & Daily & $3(33.3)$ & $5(55.6)$ & $1(11.1)$ & $0(0.0)$ \\
\hline & No & $52(34.2)$ & $34(22.4)$ & 28 (18.4) & $38(25.0)$ \\
\hline
\end{tabular}




\begin{tabular}{|llllll|}
\hline Activity & Frequency & $\begin{array}{l}\text { Hospital } \\
\mathbf{n}(\%)\end{array}$ & $\begin{array}{l}\text { University } \\
\mathbf{n}(\%)\end{array}$ & $\begin{array}{l}\text { Housekeeper } \\
\mathbf{n}(\%)\end{array}$ & $\begin{array}{l}\text { Control } \\
\mathbf{n}(\%)\end{array}$ \\
\hline & Fortnightly & $1(20.0)$ & $0(0.0)$ & $4(80.0)$ & $0(0.0)$ \\
\hline Machine wash & Daily week & $0(0.0)$ & $0(0.0)$ & $1(100.0)$ & $0(0.0)$ \\
(clothing) & $9(37.5)$ & $3(12.5)$ & $12(50.0)$ & $0(0.0)$ \\
& No & $46(35.4)$ & $35(26.9)$ & $12(8.5)$ & $38(29.2)$ \\
& Fortnightly & $0(0.0)$ & $0(0.0)$ & $1(100.0)$ & $0(0.0)$ \\
\hline 2x week & $1(8.3)$ & $1(8.3)$ & $10(83.3)$ & $0(0.0)$ \\
\hline
\end{tabular}

According to the report of cleaning workers, hypochlorite, multipurpose products, powder, formaldehyde, disinfectants, laundry detergent and liquid soap were the main products used that were related to respiratory symptoms (Table 3 ). 
Table 3

Main products used and respiratory symptoms

\begin{tabular}{|c|c|c|c|c|}
\hline Study group/ product & Hospital & University & Housekeeper & Odds \\
\hline Bleach & $\mathrm{N}(\%)$ & $\mathrm{N}(\%)$ & $\mathrm{N}(\%)$ & \\
\hline Yes & $28(52.8)$ & $20(37.7)$ & $25(49.0)$ & 0.27 \\
\hline No & $25(47.2)$ & $33(62.3)$ & $26(51.0)$ & \\
\hline \multicolumn{5}{|l|}{ Multi-use } \\
\hline Yes & $16(45.7)$ & $9(25.7)$ & $10(28.6)$ & 0.225 \\
\hline No & $37(30.3)$ & $44(36.1)$ & $41(33.6)$ & \\
\hline \multicolumn{5}{|l|}{ Dust } \\
\hline Yes & $3(12.5) \star$ & $9(37.5)$ & $12(50.0)$ & $0.037 *$ \\
\hline No & $50(37.6)$ & $44(44,9)$ & $39(29.3)$ & \\
\hline \multicolumn{5}{|l|}{ Formalin } \\
\hline Yes & $2(22.2)$ & $6(66.7)$ & $1(11.1)$ & 0.092 \\
\hline No & $51(34.5)$ & $47(31.8)$ & $50(33,8)$ & \\
\hline \multicolumn{5}{|l|}{ Disinfectants } \\
\hline Yes & $3(42.9)$ & $4(57.1)$ & $0(0.0)$ & 0.154 \\
\hline No & $50(33.3)$ & 49 (32.7) & $51(34.0)$ & \\
\hline \multicolumn{5}{|l|}{ Washing powder } \\
\hline Yes & $1(25.0)$ & $2(50.0)$ & $1(25,0)$ & 0.785 \\
\hline No & $52(34.0)$ & $51(33,3)$ & $50(32,7)$ & \\
\hline \multicolumn{5}{|l|}{ Liquid soap } \\
\hline Yes & $0(0.0)$ & $1(50.0)$ & $1(50.0)$ & 0.596 \\
\hline No & $53(34.2)$ & $52(33.5)$ & $50(32.3)$ & \\
\hline \multicolumn{5}{|l|}{ Intercap } \\
\hline Yes & $0(0,0)$ & $1(100.0)$ & $0(0.0)$ & 0.373 \\
\hline No & $53(34.0)$ & $52(33.3)$ & $51(32.7)$ & \\
\hline
\end{tabular}

*The hospital group reported fewer respiratory symptoms related to dust than to other substances. 


\begin{tabular}{|lllll|}
\hline Study group/ product & Hospital & University & Housekeeper & Odds \\
\hline Acid & & & & \\
\hline Yes & $0(0.0)$ & $1(100.0)$ & $0(0.0)$ & 0.373 \\
\hline No & $53(34.0)$ & $52(33.3)$ & $51(32.7)$ & \\
\hline Softener & & & $1(100.0)$ & 0.351 \\
\hline Yes & $0(0.0)$ & $0(0.0)$ & $50(32.1)$ & \\
\hline No & $53(34.0)$ & $53(34.0)$ & & \\
\hline *The hospital group reported fewer respiratory symptoms related to dust than to other substances. \\
\hline
\end{tabular}

\section{Nasal swab test}

In the analysis of the cellularity in the nasal swab, it was not possible to observe a difference in relation to the percentage of eosinophils among the groups (Fig. 2A). A higher percentage of neutrophils was observed in the hospital and University groups compared to the control ( $p \leq 0.001)$ (Fig. 2B). The percentage of lymphocytes in the control group was lower than that in the other groups $(p \leq 0.001)$ (Fig. 2C). The percentage of macrophages in the hospital and university groups was significantly lower than that in the housekeeper and control ( $p \leq 0.001)$ (Fig. 2D).

The cellularity in the nasal swab of the cleaning workers was also compared according to the length of performance of the labour activity: up to one year, two to five years and more than five years. A lower percentage of eosinophils was observed among the housekeeper group in relation to the hospital for the workers with up to a year of cleaning service $(p<0.05)($ Fig. $3 A$ and Table 4$)$.

Table 4

Nasal swab neutrophils and eosinophils as years in cleaning work, by job location

\begin{tabular}{|c|c|c|c|c|c|c|c|c|}
\hline \multirow{3}{*}{$\begin{array}{l}\text { Job tenure } \\
\text { (years) }\end{array}$} & \multicolumn{2}{|c|}{ Hospital group } & \multicolumn{4}{|c|}{ University group } & \multicolumn{2}{|l|}{$\mathrm{p}$} \\
\hline & Eos(\%) & Neut(\%) & Eos(\%) & Neut(\%) & $\operatorname{Eos}(\%)$ & Neut(\%) & Eos & Neut \\
\hline & \multicolumn{2}{|c|}{$($ Mean $\pm s d)$} & \multicolumn{2}{|c|}{ (Mean $\pm s d)$} & \multicolumn{2}{|c|}{ (Mean $\pm s d)$} & & \\
\hline 1 & $\begin{array}{l}0,09 \pm \\
0.06\end{array}$ & $\begin{array}{l}55.59 \pm \\
7.65\end{array}$ & $\begin{array}{l}0.83 \pm \\
0.72\end{array}$ & $\begin{array}{l}37.16 \pm \\
15.73\end{array}$ & $\begin{array}{l}1.04 \pm \\
0.62^{*}\end{array}$ & $\begin{array}{l}43.82 \pm \\
7.82\end{array}$ & 0.05 & NS \\
\hline $2-5$ & $\begin{array}{l}0.09 \pm \\
0.05\end{array}$ & $\begin{array}{l}63.07 \pm \\
8.08\end{array}$ & $\begin{array}{l}2.82 \pm \\
2.45\end{array}$ & $\begin{array}{l}47.62 \pm \\
8.13\end{array}$ & $\begin{array}{l}0.34 \pm \\
0.28\end{array}$ & $\begin{array}{l}43.14 \pm \\
7.00\end{array}$ & NS & NS \\
\hline$>5$ & $\begin{array}{l}0.09 \pm \\
0.05\end{array}$ & $\begin{array}{l}36.07 \pm \\
9.59\end{array}$ & $\begin{array}{l}0.43 \pm \\
0.36\end{array}$ & $\begin{array}{l}43.25 \pm \\
9.74\end{array}$ & $\begin{array}{l}1.00 \pm \\
0.83\end{array}$ & $\begin{array}{l}33.40 \pm \\
8.24\end{array}$ & NS & NS \\
\hline
\end{tabular}

${ }^{*} \mathrm{p}<0.05$ Housekeeper compared to hospital. 
NS: not significant. " $p$ ": value significant.

\section{Questionnaires}

Regarding wheezing symptoms (that occurred in the absence of a cold), the hospital and housekeeper groups presented a higher frequency of symptoms than the control did $(p \leq 0.05)$ (Table 4A). We observed that cleaning workers had a higher frequency of symptoms than office workers did, with the exception of the symptoms "asthma attack" and "stop to rest while walking" (Table 5A). In relation to the symptom of "accompanying other people's walking", the housekeeper group presented a lower frequency of this complaint than did the others $(p<0.01)($ Table $5 A)$. 
Table 5

Primarily reported airway symptoms, asthma and rhinitis, as well as reported symptoms related to or aggravated by job

\begin{tabular}{|c|c|c|c|c|c|}
\hline & $\begin{array}{l}\text { Hospital } \\
\text { N (\%) }\end{array}$ & $\begin{array}{l}\text { University } \\
N(\%)\end{array}$ & $\begin{array}{l}\text { Housekeeper } \\
N(\%)\end{array}$ & $\begin{array}{l}\text { Control } \\
\mathrm{N}(\%)\end{array}$ & $\mathbf{p}$ \\
\hline \multicolumn{6}{|l|}{ A. Symptom } \\
\hline Wheezing & $\begin{array}{l}16 \\
(39.0)\end{array}$ & $11(26,8)$ & $14(34.1)$ & $\begin{array}{l}0 \\
(0.0) *\end{array}$ & $\begin{array}{l}< \\
0.05\end{array}$ \\
\hline Wheezing (not cold) & $9(45.0)$ & $3(15.0)$ & $8(40.0)$ & $0(0.0)$ & $\dot{0} 05$ \\
\hline Chest tightness (night) & $\begin{array}{l}12 \\
(34.3)\end{array}$ & $8(22,9)$ & $15(42.9)$ & $\underset{*}{0}(0.0)$ & $\stackrel{<}{0.05}$ \\
\hline Shortness of breath & $\begin{array}{l}10 \\
(37.0)\end{array}$ & $8(29,6)$ & 9 (33.3) & $0(0.0)$ & $\dot{0} 05$ \\
\hline Coughing fit (night) & $\begin{array}{l}14 \\
(35.0)\end{array}$ & $14(35,0)$ & $12(30.0)$ & $0(0.0)$ & $\begin{array}{l}<.05 \\
0.05\end{array}$ \\
\hline Asthma attack & $2(22.2)$ & $4(44.4)$ & $3(33.3)$ & $0(0.0)$ & 0.16 \\
\hline Cough upon waking & $7(38.9)$ & $2(11.1)$ & $9(50.0)$ & $\underset{*}{0}(0.0)$ & $\dot{0.05}$ \\
\hline Breathlessness & $\begin{array}{l}20 \\
(43.5)\end{array}$ & $13(28.3)$ & $13(28.3)$ & $0(0.0)$ & $\stackrel{<}{0.05}$ \\
\hline Walking alongside other people & $\begin{array}{l}45 \\
(34.4)\end{array}$ & $36(27.5)$ & $13(9.9) * *$ & $\begin{array}{l}37 \\
(28.2)\end{array}$ & $\dot{0} 01$ \\
\hline Stop to rest while walking & $5(41.7)$ & $3(25.0)$ & $4(33.3)$ & $0(0.0)$ & 0.23 \\
\hline Sneezing, runny nose & $\begin{array}{l}22 \\
(45.8)\end{array}$ & $12(25.0)$ & $14(29.2)$ & $0(0.0)$ & $<.05$ \\
\hline Rhinitis (reported) & $\begin{array}{l}16 \\
(59.3)\end{array}$ & $6(22.2)$ & $5(18.5)$ & $\underset{*}{0}(0.0)$ & $\dot{0} 05$ \\
\hline \multicolumn{6}{|l|}{$\begin{array}{l}\text { B. Asthma symptoms related to or } \\
\text { aggravated by job }\end{array}$} \\
\hline \multicolumn{6}{|c|}{ * $\mathrm{p}<0.05$ : Control group compared to the others. } \\
\hline \multicolumn{6}{|c|}{$\star \star p<0.01$ : Housekeeper group compared to others for "walking alongside other people". } \\
\hline \multicolumn{6}{|c|}{$+p=0.06$ Hospital group compared to the university and housekeeper groups. } \\
\hline \multicolumn{6}{|c|}{${ }^{++} p<0.01$ University group compared to the hospital and housekeeper groups. } \\
\hline \multicolumn{6}{|c|}{$\begin{array}{l}\text { Abbreviations: ART: job-related asthma symptoms. AAT: aggravated asthma symptoms by } \\
\text { occupational activity. RRT: job-related rhinitis symptoms. RAT: aggravated rhinitis symptoms by } \\
\text { occupational activity. NS: not significant. "p": value significant. }\end{array}$} \\
\hline
\end{tabular}




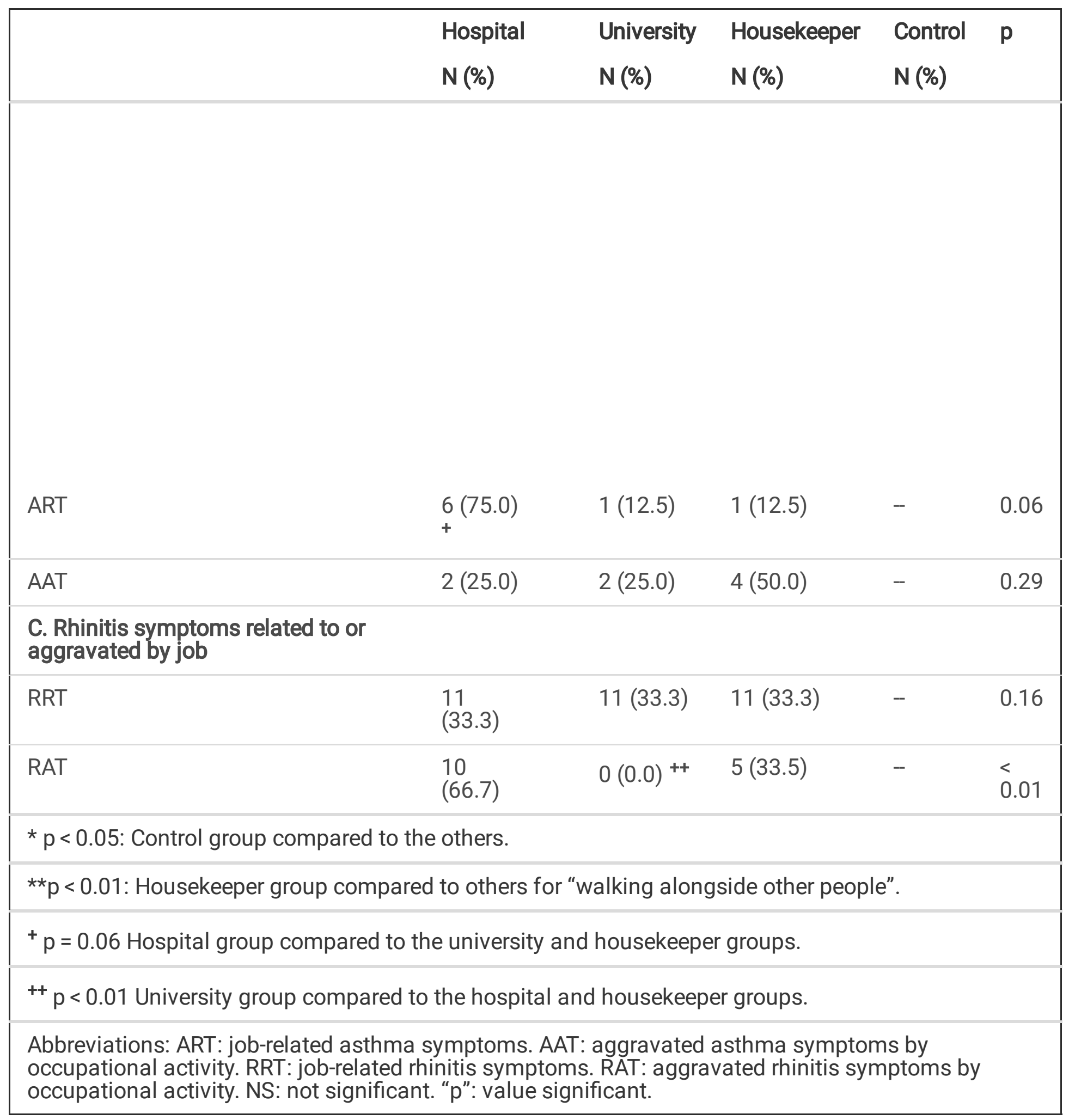

Cleaning workers were questioned about the onset and worsening of asthma or rhinitis symptoms. If the symptoms of asthma appeared only after the beginning of their cleaning work, the symptoms were considered to indicate "work-related asthma" (ART); if these symptoms already existed and worsened after participants started their cleaning work, the symptoms were referred to as "work-related asthma" (AAT). The same was considered for rhinitis symptoms, classified as "work-related rhinitis" (RRT) if the onset occurred after participants began their cleaning work and "work-related rhinitis" (RAT) if they already existed and worsened after performing professional cleaning (Tables 5B and 5C). 
Thus, the hospital group reported more symptoms in relation to ART than did the university and housekeeper groups $(p=0.06)$. In relation to AAT, there was no difference among the groups (Table 5B); the same occurred in relation to RRT (Table 4C). However, in relation to RAT, the university group reported more symptoms than did the hospital and housekeeper ( $p \leq 0.001)$ (Table 5C).

\section{Discussion}

We showed a higher percentage of neutrophils in the hospital and university groups than in the control and a decreased percentage of macrophages in the housekeeper and control groups than in the hospital and university. The percentage of lymphocytes increased in the university, hospital, housekeeper and control groups than in the hospital and university. A lower percentage of eosinophils was observed in the housekeeper group than in the hospital group among the workers with up to a year of cleaning service experience.

Our results reinforce those of previous studies in which cleaning activities were associated with workrelated asthma, as well as studies that found an excess risk of asthma among cleaners [22].

As exemplified in a study on the inflammatory process in the airways of patients with allergic and nonallergic asthma, eosinophils play an important role in the allergic inflammatory process. In the airways, inflammation is the result of complex interactions between inhaled allergens, immune cells and structural cells, such as epithelial cells, endothelial cells and fibroblasts. These interactions are mediated through cell-cell contacts and the release of several mediators, such as cytokines, chemokines and neuropeptides. T lymphocytes may also have a central role in the initiation of the allergic immune response, besides contributing to the chronic airway inflammatory response, airway remodeling and respiratory symptoms [23]. Neutrophils have also an important role in inflammation associated with asthma, including in the severe asthma phenotype where neutrophilic inflammation predominates [24].

The incidence of occupational respiratory diseases is underestimated both by the difficulty of diagnostic confirmation and by the reluctance of the worker who often does not seek medical care to confirm the diagnosis for fear of losing his or her job. Even so, the growing increase observed in the incidence of occupational diseases has drawn increasing health-related attention to the work environment [25].

Symptomatology in work-related respiratory disease is an extremely important factor to be considered by health professionals [8]. Our findings revealed that major complaints such as wheezing, chest tightness, shortness of breath, coughing, sneezing, runny nose and rhinitis were present only in the cleaning worker groups. It should be noted that water-soluble cleaning products have the capacity to irritate the upper airways [26].

Our study also revealed that the prevalence of asthma was higher, not only among hospital employees or housekeepers but also among workers from all cleaning groups, showing that professional cleaning activities could be related to work-related asthma, since no professional in the control group was identified as having asthma. These results are consistent with those of many other studies [27][9][28]. 
Jaakkola et al. [29] evaluated the relationship between occupation and the risk of developing asthma in adulthood, classifying occupations according to the potential exposure to inhalants that cause asthma. Of the predominantly male occupations, work in areas involving metal exposure (odds ratio $=4.52, \mathrm{Cl}$ : $2.35-8.70$ ) and forestry (odds ratio $=6.00, \mathrm{Cl}$ : $0.96-37.5$ ) were among the most important determinants of the development of asthma. For women, the risk of developing asthma was higher among waitress activities (odds ratio $=3.03, \mathrm{Cl}: 1.10-8.31$ ) than among work with cleaners (odds ratio $=1.42, \mathrm{Cl}$ : $0.81-$ 2.48 ) and dental work (odds ratio $=4.74, \mathrm{Cl}: 0.48-46.5$ ).

The performance of cleaning services as a risk factor for developing asthma was described in a study by Karjalainen et al. [30] that followed up with cleaning and office professionals for 12 years, noting that the odds ratio for asthma among cleaners was 1.5 -fold ( $\mathrm{Cl}$ of 1.43-1.57) higher than that among professionals working in offices.

The number of women in our research was higher than the number of men in all groups of workers studied. Maçãira et al. [20] showed the importance of studying this population, given that the respiratory morbidity in internal cleaning workers in the metropolitan region of São Paulo reflected twice the length of exposure to risk factors for respiratory diseases, and the prevalence of inhaled accidents in women was three times higher than that in men.

Exposure to cleaning products is another known risk factor, and several studies show that an individual's susceptibility should also be taken into account, since although the work environment is the same for different individuals, some develop respiratory and other diseases do not [28][29].

Atopy and smoking are some of the characteristics described in the literature as factors that contribute to this scenario [31]. It should be emphasized that in this protocol, all subjects were excluded from active tobacco use, with only a few former smokers, representing less than $2.5 \%$ of the population studied in our study (four individuals).

It is known that nasal and ocular symptoms are more important in the presence of high-molecular-weight agents than in the presence of lower-molecular-weight agents. Among cleaning workers, the use of lowmolecular-weight products is more common, and many of these products are irritant [20].

Rhinitis of allergic origin may or may not induce the onset of asthma in people who have never had pulmonary diseases [32], such as in the study by Bauchau and Durham [33], who demonstrated that allergic rhinitis was more prevalent among cleaning professionals than in the general population. These data corroborate our findings, which demonstrated that individuals from the three groups of cleaning workers have more respiratory symptoms than office workers do.

The data found in our study on rhinitis demonstrated that both the presence of rhinitis-defining symptoms and self-reported rhinitis were greater among cleaners than among office workers. However, there was no relationship between these variables and the percentage of eosinophils or neutrophils. The absence of this relationship can be justified by the lack of specificity of the symptom questionnaires for 
the diagnosis of work-related rhinitis, since these are subjective and since we observed that there was an increase in the percentages of these cells.

The use of a score to assess the prevalence of asthma was validated by de Fátima Maçãira and coworkers [20], who used the ISAAC asthma module, which was composed of eight dichotomous aspects of asthma. The authors compared the responses between asthmatics with clinical diagnosis and healthy individuals (controls), with a sensitivity of $93 \%$ and specificity of $100 \%$ when using the cut-off score in the information set. Thus, despite the absence of clinical tests to prove the existence of asthma and rhinitis in our population, the high specificity and sensitivity of the scores justify the use of this instrument.

Folletti et al. [34] systematically reviewed 24 studies addressing the relationship between clean-up work and the risk of asthma and rhinitis and rephrased that an increased risk of asthma or rhinitis was demonstrated in $79 \%$ of the included epidemiological studies. Confirmation of this information was made mainly by objective tests, such as bronchial hyperreactivity or airflow obstruction. The specific causes associated with the onset of asthma and rhinitis were the level of exposure to cleaning products, sprays, bleach, ammonia, product mix and specific work tasks.

In our study the time of service as well as the hours worked were crossed with the information of respiratory symptoms. We identified that the service time between the groups studied was the same. After this, we evaluated the differences among 3 service time ranges (up to 1 year, 2 to 5 years and over 5 years) and asthma and rhinitis symptoms.

In the first evaluation, there was no difference in asthma symptoms among workers according to the length of service intervals. However, for rhinitis symptoms, university workers with less than 1 year of functioning had fewer symptoms than the others did. These results differ from those found by Slavin [35] that report that the incidence of rhino conjunctival symptoms with occupational aetiology is higher in the first 12 to 20 months of professional activity, with a progressive increase when the exposure is continuous for 24 months.

Having to work over 20 hours weekly was more common among hospital workers with asthma symptoms. We believe that a longer work time is directly linked to the occurrence of more symptoms; the same result was found when symptoms of rhinitis were evaluated and rhinitis was confirmed, with a higher number of working hours evidenced in hospital workers. However, the alterations found in our population did not express nasal cellularity. In the analysis of the correlation between the time of service and the percentage of eosinophils and neutrophils, no significant difference was found.

When the type of analysis was adjusted for comparison rather than correlation, we identified that hospital employees and day labourers with less than 1 year of professional performance differed from each other with respect to the percentage of eosinophils but not neutrophils. Hospital workers have lower percentages of eosinophils, followed by housekeepers, and finally, university workers have higher percentages of eosinophils. These results, together with the significant values found for the duration of 
symptoms in professionals working in hospitals, convey that this professional category is more affected in both symptomatology and cellularity.

Considering the eosinophil count results in subjects with rhinitis from previous studies [36][[37] and comparing these values to those found in our study, it can be verified that the rate of eosinophils does not correspond to that expected for individuals with rhinitis in all groups studied, i.e., greater than $5 \%$. However, the percentages of the three groups of cleaning workers were higher than those found in the control group (hospital: $0.7 \pm 2.4$; university: $1.2 \pm 3.4$; housekeeper: $0.7 \pm 1.7$ control: $0.05 \pm 0.1$; percentages of eosinophils).

This same justification is exemplified in the study by Pal et al. [38], that showed that the difference in the mean eosinophil counts of patients with allergic rhinitis and controls was statistically significant, and a nasal smear eosinophil count of $>0.3$ per high-power field (HPF) had $100 \%$ specificity and $100 \%$ positive predictive value for allergic rhinitis. Asthma was associated with allergic rhinitis in $40 \%$ of patients; an association was not found between nasal smear eosinophil count and the symptoms, duration, type, and severity of allergic rhinitis or coexistent asthma. These authors conclude that an eosinophil count of $>0.3$ per HPF in nasal smears is a highly specific criterion for the diagnosis of allergic rhinitis. When grouping and comparing all cleaners who answered "yes" to the question of the presence of rhinitis and asthma regardless of length of service, these responses differed significantly for those who answered negatively to the same questions. As found in this study, evidence of changes in cell rates related to work-related rhinitis is described in several other studies [39][40].

Lovato et al. [41] compared a group of carpenters with non-exposed individuals to determine whether exposure to wood dust was correlated with specific patterns of inflammatory or infectious rhinitis. The authors identified that carpenters reported significantly more nasal symptoms than the control group $(p=$ $0.0007)$. The nasal smears of the carpenter group contained significantly more neutrophils $(p<0.00001)$ and lymphocytes $(p=0.02)$ than did those of the control, indicating that nasal cytology was able to reveal chronic inflammatory rhinitis in a significant proportion of carpenters, highlighting the potential of the technique in the screening of this pathology.

Gelardi et al. [42] also agree with the potential of the nasal cytology technique and emphasize that it deserves it place in the arsenal of diagnostic techniques for chronic rhinitis because it is an easy, reliable and inexpensive method and in the absence of other diagnostic tools, it can be used to provide adequate treatment to patients.

When investigating inflammatory factors in children with rhinitis and asthma, Marcucci and co-workers [43] found significantly higher IgE levels in the nasal mucosa during the summer, although the allergen in question (mites) was more prevalent in the winter, as the authors state. In this way, the temperature itself of the environment in which the individual resides can be an important factor to consider.

A limitation in relation that no specific equipment was used to determine the levels of chlorine or other air components in the exposure atmosphere. The patients also did not undergo a clinical evaluation and

Page 18/26 
classification in relation to symptoms was made according to the answers to the questionnaires.

As strengths of this study, we investigated associations between asthma and occupational exposure and several cleaning agents. We believe that further studies revealing the implicit risks of using cleaning products are of great value for this profession, which has been growing in recent years in large cities. We emphasize the importance of the continued investigation. In addition, future studies are necessary can clarify the risk of the use of these chemical agents, with the goal of greater adherence to the use of personal protective equipment, as well as preventive measures to minimize the risks to cleaning employees regardless of where they work.

\section{Conclusions}

Cleaning workers had upper airway inflammation, as well as symptoms of asthma and rhinitis, regardless of the workplace to which they were exposed. Although previous studies have shown that cumulative cleaning time is an asthma-related risk factor, cleaning work time was not related to nasal inflammation and respiratory symptoms in this population.

\section{Declarations}

\section{Acknowledgements}

The authors are thankful to IAMSPE, LIM20-FMUSP and Fundação de Amparo à Pesquisa do Estado de São Paulo (FAPESP) and UNICID for assistance and support.

\section{Authors' contributions}

All authors contributed to the study conception and design. Material preparation, data collection and analysis were performed by ERP, SNF, BMSR. The analysis of data, samples and the initial version of the manuscript was performed by CMFL, BS, CESG. The statistics and initial review were carried out by ATC. The first draft of the manuscript was written by Renato Fraga Righetti, Edinéia Rosa da Paz, Beatriz Mangueira Saraiva-Romanholo, Soraia Nogueira Felix and all authors commented on previous versions of the manuscript. Review and supervision were performed by Soraia Nogueira Felix, Milton de Arruda Martins, lolanda de Fátima Lopes Calvo Tibério, Beatriz Mangueira Saraiva-Romanholo. All authors read and approved the final manuscript.

\section{Availability of data and material.}

All relevant data are within the paper and; the main data can also be accessed at:

https://clinicaltrials.gov/ct2/show/results/NCT03311048. Clinical Trial Registration: ClinicalTrials.gov; No.: NCT03311048; URL: www.clinicaltrials.gov. Any additional data can be requested from the corresponding author or the last author. 


\section{Conflicts of interest/Competing interests}

We have read the journal's policy and the authors of this manuscript have declared no competing interests.

\section{Consent to participate}

Informed consent was obtained from all individual participants included in the study. All participants received explanations, signed and received a copy of the written consent form.

\section{Consent for publication}

The authors affirm that human research participants provided informed consent for publication of the study data without personal identification. In the written consent form, all participants authorized the publication of the data for this study, without any individual identification related to the participants. The confidentiality and privacy of any personal data were respected in this study.

\section{Ethics approval}

This study was approved by the IAMSPE Research Ethics Committee (http://www.iamspe.sp.gov.br/pesquisas/), protocol number 457.41 in accordance with the ethical standards as laid down in the 1964 Declaration of Helsinki. The study was registered and approved according to the country's standards on the Brazil Platform (Plataforma Brasi), number 72876517.0.0000.0068(http://plataformabrasil.saude.gov.br/login.jsf).

\section{Financial interests}

The authors declare they have no financial interests.

\section{Funding}

This work has been supported by:

1) Grant number 2014/26829-4, Fundação de Amparo à Pesquisa do Estado de São Paulo (FAPESP, São Paulo, SP, Brazil (https://fapesp.br).

2) LIM 20 FMUSP, Sao Paulo, SP, Brazil - support with consumables, equipment and support (https://limhc.fm.usp.br/portal/lim20-laboratorio-de-terapeutica-experimental/).

The funders had no role in study design, data collection and analysis, decision to publish, or preparation of the manuscript.

\section{References}


1. Francis HC, Prys-Picard CO, Fishwick D, Stenton C, Burge PS, Bradshaw LM, et al. Defining and investigating occupational asthma: a consensus approach. Occup Environ Med. 2007 Jun;64(6):361-5.

2. Nicholson PJ, Cullinan P, Taylor AJN, Burge PS, Boyle C. Evidence based guidelines for the prevention, identification, and management of occupational asthma. Occup Environ Med. 2005 May;62(5):2909.

3. Le Moual N, Zock J-P, Dumas O, Lytras T, Andersson E, Lillienberg L, et al. Update of an occupational asthma-specific job exposure matrix to assess exposure to 30 specific agents. Occup Environ Med. 2018 Jul;75(7):507-14.

4. Vandenplas O, D’Alpaos V, Evrard G, Jamart J, Thimpont J, Huaux F, et al. Asthma related to cleaning agents: a clinical insight. BMJ Open. 2013 Sep;3(9):e003568.

5. Mendonça EMC, Algranti E, de Freitas JBP, Rosa EA, dos Santos Freire JA, de Paula Santos Ud U, et al. Occupational asthma in the city of São Paulo, 1995-2000, with special reference to gender analysis. Am J Ind Med. 2003 Jun;43(6):611-7.

6. Malo J-L, Tarlo SM, Sastre J, Martin J, Jeebhay MF, Le Moual N, et al. An official American Thoracic Society Workshop Report: presentations and discussion of the fifth Jack Pepys Workshop on Asthma in the Workplace. Comparisons between asthma in the workplace and non-work-related asthma. Ann Am Thorac Soc. 2015 Jul;12(7):99-110.

7. Global Initiative for Asthma. Global Strategy for Asthma Management and Prevention. 2019. Available from: www.ginasthma.org. GLOBAL STRATEGY FOR Global Strategy for Asthma Management and Prevention. Glob Initiat Asthma Glob Strateg Asthma Manag Prev 2019 Available from www.ginasthma.org. 2019.

8. Baur X, Sigsgaard T, Aasen TB, Burge PS, Heederik D, Henneberger P, et al. Guidelines for the management of work-related asthma. Eur Respir J. 2012 Mar;39(3):529-45.

9. Folletti I, Siracusa A, Paolocci G. Update on asthma and cleaning agents. Curr Opin Allergy Clin Immunol. 2017 Apr;17(2):90-5.

10. Pralong JA, Cartier A, Vandenplas O, Labrecque M. Occupational asthma: new low-molecular-weight causal agents, 2000-2010. J Allergy. 2012;2012:597306.

11. Galli SJ, Tsai M. IgE and mast cells in allergic disease. Nat Med. 2012 May;18(5):693-704.

12. Quirce S, Sastre J. Occupational asthma: clinical phenotypes, biomarkers, and management. Curr Opin Pulm Med. 2019 Jan;25(1):59-63.

13. Kay AB. The role of T lymphocytes in asthma. Chem Immunol Allergy. 2006;91:59-75.

14. Mamessier E, Milhe F, Guillot C, Birnbaum J, Dupuy P, Lorec A-M, et al. T-cell activation in occupational asthma and rhinitis. Allergy. 2007 Feb;62(2):162-9.

15. Rocha MRA, Marin MJS, Macias-Seda J. Living, working conditions and mental health: A study with Brazilian and Spanish workers who work in hospital cleaning services. Cienc e Saude Coletiva. 2020;25(10):3821-32. 
16. Eurofound and International Labour Organization. Working conditions in a global perspective [Internet]. 2019. 196 p. Available from:

https://www.eurofound.europa.eu/publications/report/2019/working-conditions-in-a-globalperspective.

17. Burney PGJ, Luczynska C, Chinn S, Jarvis D. The European Community Respiratory Health Survey. Eur Respir J [Internet]. 1994;7(5):954-60. Available from: https://erj.ersjournals.com/content/7/5/954.article-info.

18. Ribeiro M, Angelini L, Robles-Ribeiro PG, Stelmach R, Santos U, de P, Terra-Filho M. Validation of the Brazilian-Portuguese version of the European Community Respiratory Health Survey in asthma patients. J Asthma. 2007 Jun;44(5):371-5.

19. Asher MI, Keil U, Anderson HR, Beasley R, Crane J, Martinez F, et al. International Study of Asthma and Allergies in Childhood (ISAAC): rationale and methods. Eur Respir J. 1995 Mar;8(3):483-91.

20. de Fátima Maçãira E, Algranti E, Medina Coeli Mendonça E, Antônio Bussacos M. Rhinitis and asthma symptoms in non-domestic cleaners from the Sao Paulo metropolitan area, Brazil. Occup Environ Med. 2007 Jul;64(7):446-53.

21. Ronchetti R, Villa MP, Martella S, La Grutta S, Ronchetti F, Biscione GL, et al. Nasal cellularity in 183 unselected schoolchildren aged 9 to 11 years. Pediatrics. 2002 Dec;110(6):1137-42.

22. Mäkelä R, Kauppi $P$, Suuronen $K$, Tuppurainen $M$, Hannu T. Occupational asthma in professional cleaning work: a clinical study. Occup Med (Lond). 2011 Mar;61(2):121-6.

23. Amin K. The Role of the T lymphocytes and Remodeling in Asthma. Inflammation. 2016 Aug;39(4):1475-82.

24. Davis KU, Sheats MK. The Role of Neutrophils in the Pathophysiology of Asthma in Humans and Horses. Inflammation. 2021 Apr;44(2):450-65.

25. De Matteis S, Heederik D, Burdorf A, Colosio C, Cullinan P, Henneberger PK, et al. Current and new challenges in occupational lung diseases. Eur Respir Rev an Off J Eur Respir Soc. 2017 Dec;26(146).

26. Svanes $\varnothing$, Bertelsen RJ, Lygre SHL, Carsin AE, Antó JM, Forsberg B, et al. Cleaning at Home and at Work in Relation to Lung Function Decline and Airway Obstruction. Am J Respir Crit Care Med. 2018 May;197(9):1157-63.

27. Zock J-P, Vizcaya D, Le Moual N. Update on asthma and cleaners. Curr Opin Allergy Clin Immunol. 2010 Apr;10(2):114-20.

28. Quirce S, Barranco P. Cleaning agents and asthma. J Investig Allergol Clin Immunol. 2010;20(7):54250. quiz $2 p$ following 550.

29. Jaakkola JJK, Piipari R, Jaakkola MS. Occupation and asthma: a population-based incident casecontrol study. Am J Epidemiol. 2003 Nov;158(10):981-7.

30. Karjalainen A, Martikainen R, Klaukka T, Saarinen K, Uitti J. Risk of asthma among Finnish patients with occupational rhinitis. Chest. 2003 Jan;123(1):283-8. 
31. Jang A-S, Choi I-S, Lee S, Nam H-S, Kweon S-S, Son M-H, et al. The effect of passive smoking on asthma symptoms, atopy, and airway hyperresponsiveness in schoolchildren. J Korean Med Sci. 2004 Apr;19(2):214-7.

32. van Aalderen WM. Childhood asthma: diagnosis and treatment. Scientifica (Cairo). 2012;2012:674204.

33. Bauchau V, Durham SR. Prevalence and rate of diagnosis of allergic rhinitis in Europe. Eur Respir J. 2004 Nov;24(5):758-64.

34. Folletti I, Zock J-P, Moscato G, Siracusa A. Asthma and rhinitis in cleaning workers: a systematic review of epidemiological studies. J Asthma. 2014 Feb;51(1):18-28.

35. Slavin RG. Occupational rhinitis. Ann allergy, asthma Immunol Off Publ Am Coll Allergy, Asthma, Immunol. 2003 May;90(5 Suppl 2):2-6.

36. Ciprandi G, Vizzaccaro A, Cirillo I, Tosca M, Massolo A, Passalacqua G. Nasal eosinophils display the best correlation with symptoms, pulmonary function and inflammation in allergic rhinitis. Int Arch Allergy Immunol. 2005 Mar;136(3):266-72.

37. Marseglia GL, Cirillo I, Vizzaccaro A, Klersy C, Tosca MA, La Rosa M, et al. Role of forced expiratory flow at $25-75 \%$ as an early marker of small airways impairment in subjects with allergic rhinitis. Allergy asthma Proc. 2007;28(1):74-8.

38. Pal I, Sinha Babu A, Halder I, Kumar S. Nasal smear eosinophils and allergic rhinitis. Ear Nose Throat J. 2017;96(10-11):E17-22.

39. Castano R, Maghni K, Castellanos L, Trudeau C, Malo J-L, Gautrin D. Proinflammatory mediators in nasal lavage of subjects with occupational rhinitis. Otolaryngol neck Surg Off $\mathrm{J}$ Am Acad Otolaryngol Neck Surg. 2010 Aug;143(2):301-3.e1.

40. Hox V, Steelant B, Fokkens W, Nemery B, Hellings PW. Occupational upper airway disease: how work affects the nose. Allergy. 2014 Mar;69(3):282-91.

41. Lovato A, Staffieri C, Ottaviano G, Cappellesso R, Giacomelli L, Bartolucci GB, et al. Woodworkers and the inflammatory effects of softwood/hardwood dust: evidence from nasal cytology. Eur Arch otorhino-laryngology Off J Eur Fed Oto-Rhino-Laryngological Soc Affil with Ger Soc Oto-RhinoLaryngology - Head Neck Surg. 2016 Oct;273(10):3195-200.

42. Gelardi M, lannuzzi L, Quaranta N, Landi M, Passalacqua G. NASAL cytology: practical aspects and clinical relevance. Clin Exp allergy J Br Soc Allergy Clin Immunol. 2016 Jun;46(6):785-92.

43. Marcucci F, Passalacqua G, Canonica GW, Frati F, Salvatori S, Di cara G, et al. Lower airway inflammation before and after house dust mite nasal challenge: an age and allergen exposure-related phenomenon. Respir Med. 2007 Jul;101(7):1600-8.

\section{Figures}




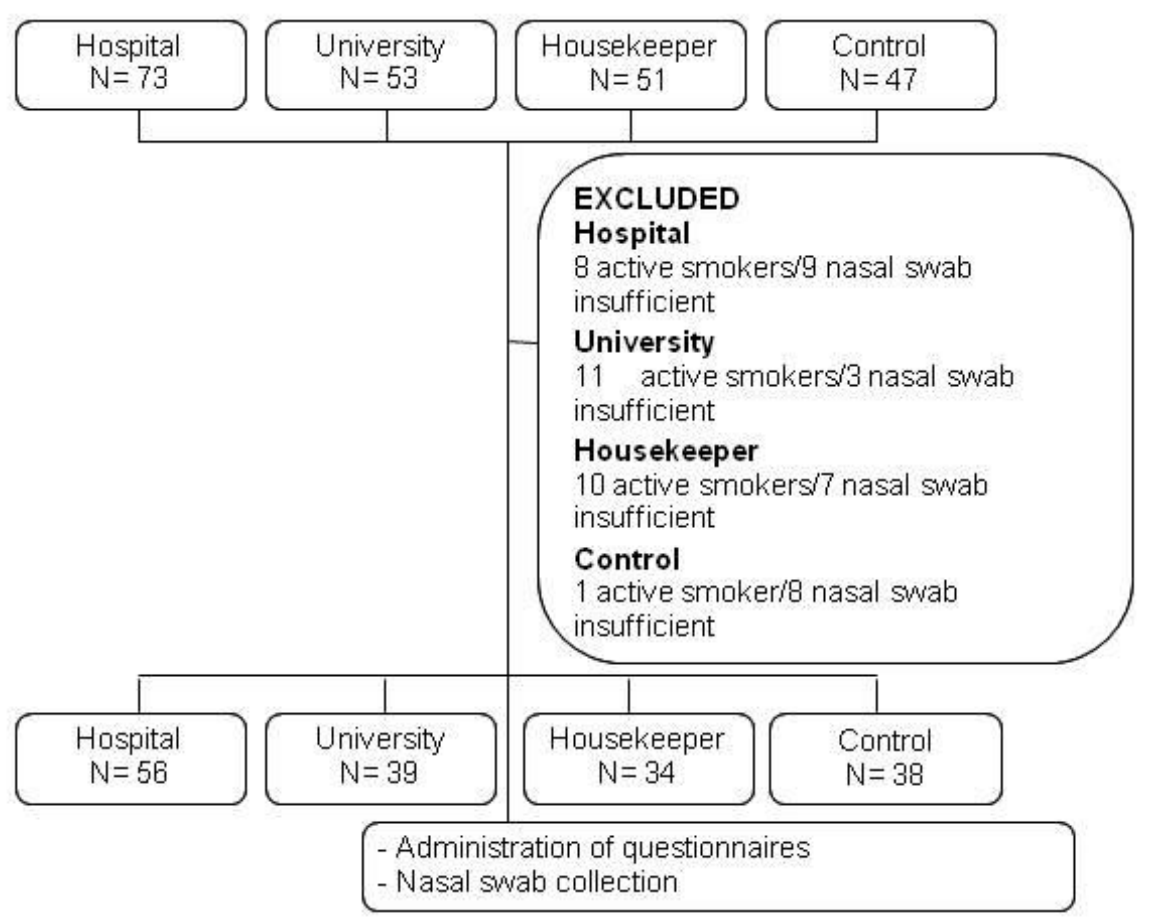

Figure 1

Study Design 

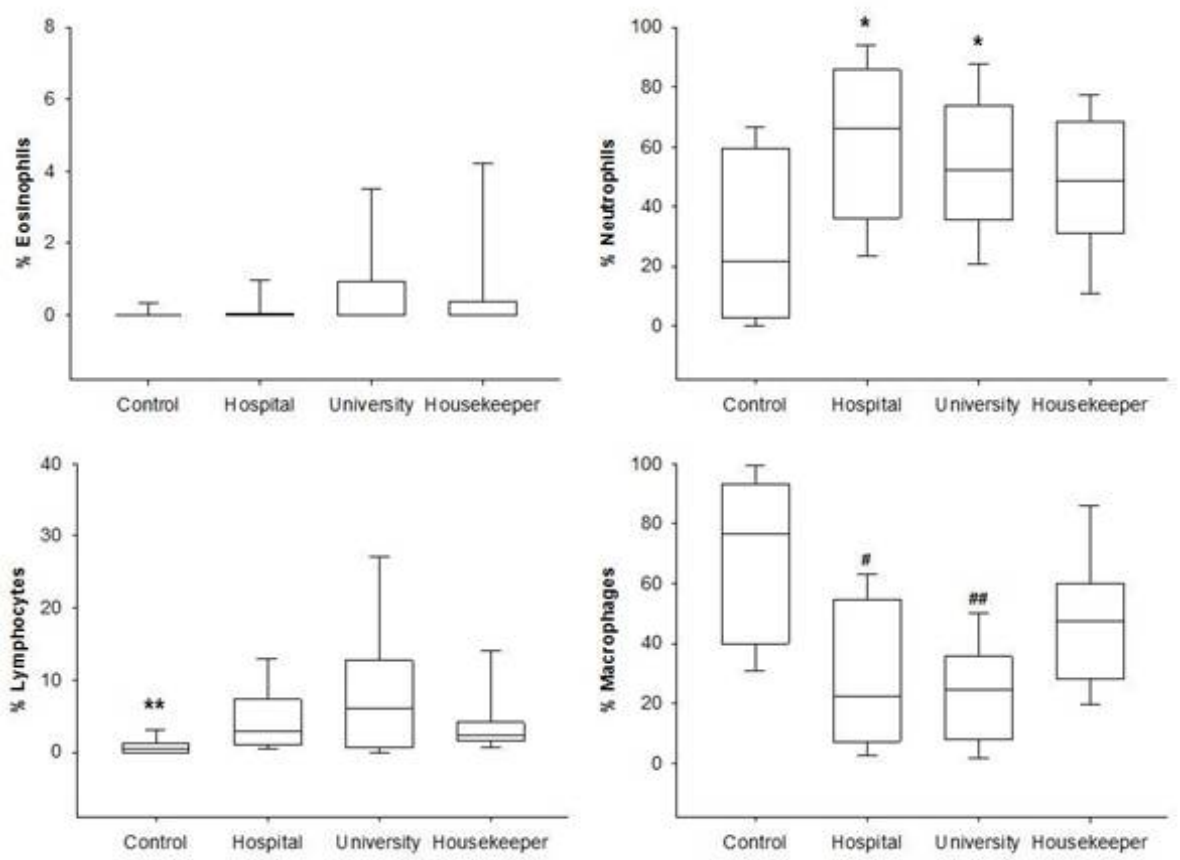

\section{Figure 2}

Nasal swab inflammatory cell percentage as workplace (\%). a. Eosinophils: no significant difference. b. Neutrophils: The hospital and university groups showed differences compared to the control group $\left({ }^{\star} \mathrm{p} \leq 0.001\right)$. c. Lymphocytes: The control group showed differences compared to the others $\left({ }^{\star \star} p \leq 0.001\right)$. d. Macrophages: The hospital and university groups showed differences compared to the housekeeper and control groups $(\#, \# \#$ $\leq 0.001)$ 


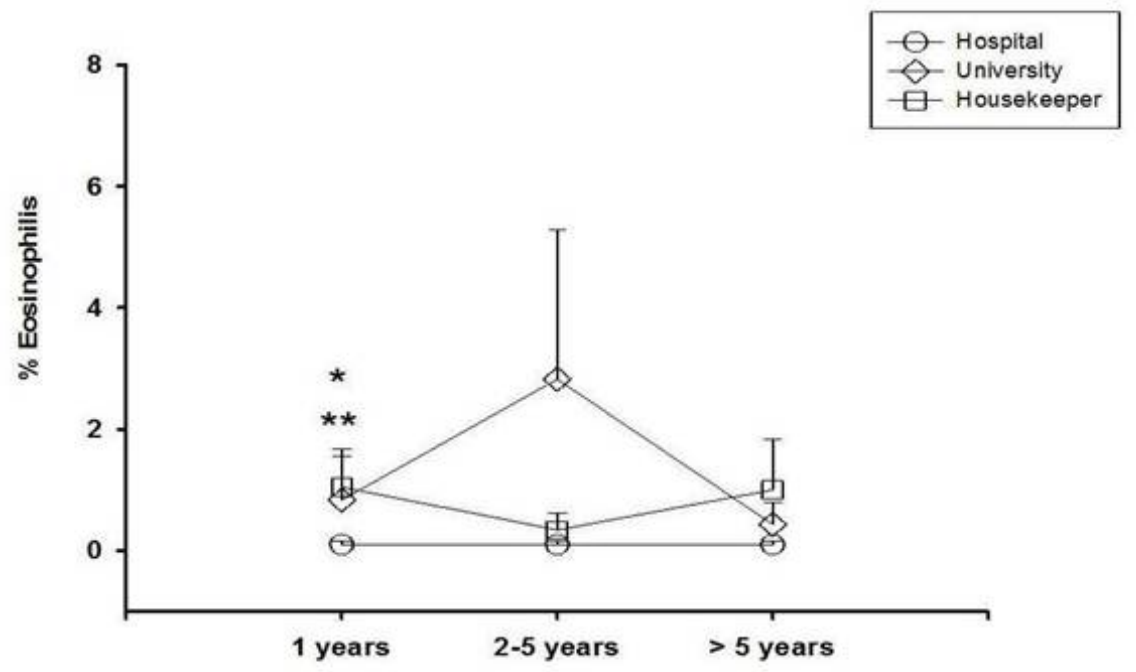

\section{Figure 3}

Nasal swab eosinophil percentage as years worked in cleaning services. ${ }^{*} \mathrm{p}=0.001$ compared to the hospital group; ${ }^{* \star} \mathrm{p}=0.001$ compared to one year of housekeeping with 2-5 years of housekeeping

\section{Supplementary Files}

This is a list of supplementary files associated with this preprint. Click to download.

- S2StrobeChecklist090421.docx 